DOI: https://doi.org/10.32839/2304-5809/2020-9-85-10

UDC $81 / 33$

Kichun Solomiia

Lviv Polytechnic National University

\title{
LINGUISTIC MEANS OF CREATING IMAGES
}

Summary. The purpose of this text is to contemplate the features of the linguistic means. The object is linguistic means of making images. The article deals with devices used for creating images of literary characters of the story. The pictures are analyzed taking under consideration extralinguistic factors, attention is paid to the image of the characters and also the speech portrait of every of them. The term «speech portrait» appeared along with the term «linguistic identity» in national linguistics in the 1960s. The term is understood differently by the linguists (S.V. Laorda, Y.S. Alysheva, S.V. Mamaeva, and T.P. Tarasenko); however, the creation of speech portraits as a method of describing the linguistic identity and reflecting the human factor in the language is becoming more and more popular in modern linguistics. The study of the speech portrait began with a study of the phonetic portrait (M.V. Panov), and then took place in the conceptual study of Y. Karaulov "The Russian Language and the Language identity». The period of 1990-2000s is represented by a series of works in which speech portraits of whole social groups and individuals (intellectuals, journalists, schoolchildren and students, politicians and state employees) are studied. In linguistics a sufficient experience of methodological and theoretical understanding of the phenomenon of speech portrait has been formed. But the share of research devoted to the speech portrait of a literary character is much smaller.

Keywords: linguistic means, image, character, individualization, extralinguistic factors.

Кічун C.B.

Національний університет «Львівська політехніка»

\section{ЛІНГВІСТИЧНІ ЗАСОБИ СТВОРЕННЯ ОБРАЗУ}

Анотація. У статті розглядаються основні засоби і прийоми, які використовуються для створення образів персонажів в літературному творі. Образи аналізуються з урахуванням екстралінгвістичних чинників, увага приділяеться зображення зовнішності героїв і мовному портрету кожного персонажа. Термін «мовленневий портрет» з'явився разом із терміном «мовна ідентичність» у вітчизняній лінгвістиці в 1960-х роках. Цей термін лінгвісти розуміють по-різному (С.В. Лаорда, Ю.С. Алишева, С.В. Мамаєва та Т.П. Тарасенко); однак створення мовленневих портретів як методу опису мовної ідентичності та відображення людського фрактора в мові стає все більш популярним у сучасній лінгвістиці. Вивчення мовного портрета розпочалося з вивчення фонетичного портрета (М.В. Панов), а потім відбулося в концептуальному дослідженні Ю. Караулова «Російська мова та мовна ідентичність». Період 1990-2000-х років представлений серією робіт, в яких представлені мовленневі портрети цілих соціальних груп та окремих людей (інтелігенції, журналістів, школярів та студентів, політиків та бюджетників). вивчали. У лінгвістиці сформовано достатній досвід методологічного та теоретичного осмислення явища мовленневого портрета. Але частка досліджень, присвячених мовленневому портрету літературного персонажа, значно менша. Образність мови письменника, вміння передати загальне через одиничне - досягається рядом мовних стилістичних прийомів. Це досягається шляхом використання зображально-виражальних засобів художнього мовлення таким чином, що вони здаються незвичними, дивними. У художньому стилі тропи виконують також естетичну фрунцію, прикрашають мовні обриси, збагачують свідомість та уяву читачів, пробуджують низку асоціацій та переживань. Основна властивість тропів - яскраво характеризувати одне явище через інше на основі їх подібності. Згідно з визначенням О. Потебні, «троп» - це слово, що використовуеться в переносному значенні для опису будь-якого явища за допомогою вторинних семантичних значень, актуалізації його внутрішньої форми. У лінгвістиці інтерес до проблеми дослідження художніх тропів розпочався ще за часів Аристотеля і триває й сьогодні. Автори, які присвятили свої праці цим проблемам: Н. Арутюнова, І. Білодід, В. Ващенко, В. Виноградова, В. Телія, О. Тараненко та інші. Дослідники підкреслювали, що засоби поетичного мовлення розкривають багатство асоціативних відтінків слова, підсилюють та виражають емоційне та оцінне забарвлення, сприяють яскравішому відтворенню обставин та героїв. Використовуючи слова в переносному чи модифікованому значенні, враховуються вторинні (конотативні) ознаки об'єкта чи явища, яке називається, основне значення слова (денотат) ігнорується. Вивчення мовних засобів бере свій початок із давніх часів і залишається актуальним сьогодні. На думку більшості вчених, основними фрунціями образно-виразних засобів мови є зорова, емоційно-експресивна та естетична. Автори українських шкільних курсів поділили засоби на дві групи: словесні та смислові. У наш час вчені продовжують відкривати правильне використання мовних засобів.

Ключові слова: лінгвістичні засоби, образ, герой, індивідуалізація, екстралінгвістичні чинники.

Tormulation of the problem. The linguistic means are the techniques and tools that the author of the work uses, telling the story. The artistic image is born in the imagination of the artist, embodied in the work created by him in one or another material form (plastic, sound, verbal) and reproduced by the imagination of the one who perceives art. Unlike other types of images (for example, pho- to-documentary or abstract-geometric), the artistic image, reflecting certain phenomena of reality, at the same time carries a holistic spiritual meaning, which organically merges the emotional and intellectual attitude of the artist to the world. This gives grounds to speak about the figurative language of art, necessary in order to embody and convey certain value-cognitive ideas, aesthetic ideas and ideals. 
The problem of the specifics of the artistic image has attracted the attention of scientists throughout the history of civilization. Therefore, there is a fairly detailed idea of this concept, thanks to the works of R. Bart, M. Bakhtin, V. Belinsky, Y. Borev, M. Epstein, G. Gachev, M. Hirschman, G. Hegel, N. Gay, K. Goranov, V. Kozhinov, O. Losev, P. Palievsky, O. Potebny, I. Rodnyanska, I. Fizer, M. Khrapchenko, F. Schelling, G. Shpet and many others.

Artistic image is a necessary constructive element of any work of art. The functioning of the artistic image, his structural content is closely related to the evolution of art systems. The idea of the image has its roots in the deep past. The term "artistic image" occurs in philosophical, christian, literary and aesthetic teachings.

Analysis of recent research and publications. The study of linguistic means dates back to ancient times and remains relevant today. According to most scholars, the main functions of pictorial and expressive means of language are visual, emotionally expressive and aesthetic. The authors of Ukrainian school courses divided the means into two groups: verbal and semantic. Nowadays, the scholars continue to discover the right use of the linguistic means.

Selection of previously unresolved parts of the overall problem. The imagery of the writer's language, the ability to convey the general through the singular - is achieved by a number of linguistic stylistic devices. This is achieved by pictorial and expressive means through the use of artistic speech in such a way that they seem unusual, strange. In the artistic style, the trails also perform an aesthetic function, decorate the language outline, enrich the consciousness and imagination of readers, awaken a number of associations and experiences. The main property of trails is to vividly characterize one phenomenon through another on the basis of their similarity. According to the definition of O. Potebny, "trope" is a word used figuratively to describe any phenomenon with the help of secondary semantic meanings, the actualization of its internal form [19, p. 213]. In linguistics, interest in the problem of studying artistic paths began in the time of Aristotle and continues today. The authors who devoted their works to these problems: N. Arutyunova, I. Bilodid, V. Vashchenko, V. Vinogradov, V. Telia, O. Taranenko and others. Researchers have emphasized that the means of poetic speech reveal the richness of associative nuances of the word, enhance and express the emotionally evaluative color, contribute to a brighter reproduction of circumstances and characters. When using words in a figurative or modified meaning, take into account the secondary (connotative) features of the object or phenomenon that is called, the main meaning of the word (denotation) is ignored.

Formulation of the article`s goals. The goals of this study is to show how the linguistic means can be used properly for creating images in different texts. Below the use of linguistic means will be pictured in order to make the successful image.

Presentation of the main research material. The success of any book is relied on the chances of the author to make a real and interesting character for the readers. It is rough, but there are some tools, which might be helpful.
Characters are imaginary persons that are given human qualities. So being a specific person along with his individual peculiarities a literary character is additionally a generalized image of a person. That is why it is mandatory not only to characterize an individual age, to create him think in an exceedingly certain way but to make the reader become inquisitive about him.

The image of a literary character consists of the many things. They are, as an example, person's temper, appearance, level of education, hobbies and inclinations, position, and others' attitude to him. These all contributes to the psychological and social portrait of the character that's revealed to the reader not only by the author's description but through the person's own speech, actions and behavior.

The way of character drawing is direct or indirect. Direct characterization tells the reader what precisely the personality of the character is. Indirect characterization shows things that reveal the personality of a personality. The author may show the reader the character in action. a personality in fiction isn't a static portrait, his movements, gestures, his development during the story inevitably progress.

Character's speech may be a marker of his age, level of education, occupation. Speech portrait of the character created by the author is embodiment of not only the inner world of the personage but also a right away reflection of the intellectual and emotional world of the author himself. So, the study of linguisticstylistic ways to make a speech portrait of a personality seems relevant within the framework of the overall study of linguistic personality, furthermore as in an exceedingly more private description of the stylistic features of the speech of the most the characters of the story of R. Dahl.

The study of the speech portrait began with a study of the phonetic portrait (M.V. Panov), and then took place in the conceptual study of Y. Karaulov "The Russian Language and the Language identity» [3]. The period of 1990-2000s is represented by a series of works in which speech portraits of whole social groups and individuals (intellectuals [4], journalists [1], schoolchildren and students [7], politicians and state employees [6]) are studied. In linguistics a sufficient experience of methodological and theoretical understanding of the phenomenon of speech portrait has been formed. But the share of research devoted to the speech portrait of a literary character is much smaller.

The object of the speech portrait's analysis are linguistic means belonging to numerous levels of language. During this case, it's possible to explain only those levels which are most important within the speech portrait of a private personality. within the study, we depend upon the lexical and syntactic levels of the language since the character is revealed most vividly there.

E.A. Goncharova is certain that speech portrait of the character will be considered from the purpose of vocabulary and syntax. She thinks that the lexical composition of the phrase gives a thought of the conceptual sphere of the character and its syntactic organization reflects the features of logical usage of those images and ideas [2, p. 98].

Speaking of a speech portrait, one cannot but mention the linguistic personality. A speech portrait is embodied in speech linguistic personality [5, p. 28]. Thus, the matter of speech portraiture is secondary 
to linguistic research of personality. Penetration of the author into the mind of the character can reveal the character's private thoughts and feelings in addition as observing him speaking. In fiction the way the character appears like and also the way he dresses, also shows what the person he is.

Below you'll see what is vital to use in work to create an image brilliantly.

1. The portrait. The image of the hero's appearance. this is often one among the methods of the character's individualization. Through the portrait, the author often reveals the inner world of the hero, the peculiarities of his character. Sometimes the thought of the hero's appearance is formed without portrait sketches, but with the assistance of a deep disclosure of his inner world, when the reader seems to finish it himself. Thus, in Pushkin's novel "Eugene Onegin" nothing is alleged about the colour of the eyes or stripes of Onegin and Tatiana, but the reader imagines them as alive.

2. Behavior. As in life, the character of the hero is revealed primarily in what he does, in deeds. The plot of the work could be a chain of events within which the characters are revealed. an individual is judged by not what he speaks about himself, but by his behavior.

3. Individualization of language. This is often also one in all the foremost important means of unveiling the hero's character, as in language an individual fully reveals himself. In times of yore there was an aphorism: "Say a word on behalf of me to determine you". The language gives a thought of the social rank of the hero, his character, education, profession, temperament and more.

4. The talent of a prose writer is set by the flexibility to reveal the hero through his language. Biography of the hero. In a work, the hero's life is depicted for a particular period so as to reveal the origins of certain character traits, the author often show us biographical information associated with his past.

Conclusions from this study and prospects. We can say that as for the linguistic means of creating the image of the character, it is proved that they play a huge role in describing not only the appearance but also in describing the character of the hero. The main and frequent means are epithets, which give a vivid figurative definition of any trait. Means of expression create a richer and brighter world, give their "flavor" to each scene and each character. If we removed from the works all means of expression, we would get a dry and academic retelling of any story that hardly anyone will ever read.

Creating the image of a person, the author selects the appropriate artistic means, this choice may be limited by the nature and genre features of the work. Thus, in drama, the portrait, landscape, interior are possible only in the author's remarks, the language characteristics and actions of the hero come to the fore as the main means of creating an image. In a lyrical work, the image of a person a lyrical hero - is created through a lyrical monologue that contains a description of experiences, the mental state of the subject of speech, as well as his manner of linguistic self-expression.

Thus, conducting a literary analysis of a work of art is an urgent problem in the practice of modern school. Specific in such an analysis is the study of pictorial and expressive means, determining their role in the literary text, which significantly increases the efficiency of the level of perception and comprehension of the author's idea of the literary text.

We are able to summarize that using linguistic means in creating images is an apparent part. The characters will look really realistic and interesting for readers.

\section{References:}

1. Gaboeva, Z.M. (2011). Rechevoy portret sovremennogo televeduschego [Speech portrait of a modern TV presenter]. Nauka i sovremennost, no. 8(3), pp. 12-15. (in Russian)

2. Honcharova, E.A. (1984). Puti linhvostylistychnoho vyrazhennya katehoriyi avtor - personazh u khudozhn'omu mystetstvi [Ways of linguo-stylistic expression of categories the author is a character in the artistic text]. Tomsk: Tomsk University. (in Russian)

3. Karaulov, Yu.N. (2010). Russkij yazyk i yazykovaya lichnost' [Russian language and linguistic identity]. Moscow: LCI. (in Russian)

4. Krysin, L.P. (2001). Sovremenniy russkiy intelekt: popitka rechevogo portreta [A modern Russian intellectual: an attempt at a speech portrait]. Russkiy yazyik $v$ nauchnom osveschenii, no. 1, pp. 90-106. (in Russian)

5. Leorda, S.V. (2006). Rechevoy portret sovremennogo studenta [Speech portrait of a modern student] (PhD Thesis). Saratov: Saratov State University N.G. Chernyshevsky. (in Russian)

6. Panova, M.N. (2004). Yazykovaya lichnost' gosudarstvennogo sluzhashchego: opyt lingvometodicheskogo issledovaniya [Language identity of a state employee: the experience of linguo-metodic research]. Moscow: Ros. University of Friendship of Peoples. (in Russian)

7. Scriabina, O.A. (2015). Na temu movnoho portretu suchasnoho studenta [On the speech portrait of a modern student]. Materialy XIX Mezhdunarodnoj nauchnoj konferencii "Ritorika v konteksteobrazovaniya $i$ kul'tury". Ryazan. (in Russian)

\section{Список літератури:}

1. Габоева 3.М. Речевой портрет современного телеведущего. Наука и совреленность. 2011. № 8-3. С. 12-15.

2. Гончарова Е.А. Пути лингвостилистического выражения категорий автор - персонаж в художественном тексте. Томск : Томский университет, 1984. 115 с.

3. Караулов Ю.Н. Русский язык и языковая личность. Изд. 7-е. Москва : ЛКИ, 2010. 264 с.

4. Крысин Л.П. Современний русский интелект: попытка речевого портрета. Русский язык в научнол освещении. 2011. № 1. С. 90-106.

5. Леорда С.В. Речевой портрет современного студента : автореф. дис. канд. фрилол. Саратов : Саратовской государственний университет им. Н.Г. Чернышевского, 2006. 32 с.

6. Панова М.Н. Языковая личность государственного служащего: дискурсивная практика, типология, механизмы формирования : дисс. д-ра филол. наук. Москва, 2004. 323 с.

7. Скрябіна О.А. На тему мовного портрету сучасного студента. Матеріали ХIX Міжнародної наукової конференції «Риторика в контексті освіти ТВ культури». Рязань, 2015. С. 146-148. 